\title{
Is Groenvlei really fed by groundwater discharged from the Table Mountain Group (TMG) Aquifer?
}

\author{
Roger Parsons* \\ Parsons \& Associates Specialist Groundwater Consultants, PO Box 2606, Somerset West, 7129, South Africa
}

\begin{abstract}
Vankervelsvlei is a unique wetland located in the stabilised dunes east of Sedgefield. Groenvlei is one of a series of 5 brackish coastal lakes along the Southern Cape coast of South Africa, but is the only one disconnected from the sea. It has been hypothesised that discharge from the underlying Table Mountain Group Aquifer sustains Vankervelsvlei, which in turn discharges into Groenvlei. This paper critically reviews the conceptual model and information on which the hypothesis was based. It is argued that the conceptual model is flawed as it does not take account of topographical and geohydrological conditions prevalent in the area. Analysis of limited hydrochemical data did not explore other possible water sources, and the electrical conductivity characteristics used to confirm the link between the wetlands and the deeper secondary aquifer also apply to $56.3 \%$ of boreholes located in a variety of aquifer types across the Western Cape Province. No information is available that supports a link to the Table Mountain Group. Rather, it appears that Vankervelsvlei is sustained by direct rainfall and there is no hydraulic link between Vankervelsvlei and Groenvlei.
\end{abstract}

Keywords: surface water/groundwater interaction, wetlands

\section{Introduction}

Groenvlei is a brackish coastal lake known for its diverse bird life and is one of the best venues for large-mouth black bass angling. It is one of a series of 5 brackish coastal lakes along the Southern Cape coast of South Africa, but is the only one disconnected from the sea. It is located about $5 \mathrm{~km}$ east of the holiday town of Sedgefield (Fig. 1). Growing concern about the impact of proposed development in the vicinity of the nearpristine wetland has highlighted the need to understand the hydrological functioning of the system.

Roets (2008) researched the wetland in the context of groundwater dependence of aquatic ecosystems associated with Table Mountain Group (TMG) Aquifers. Together with Roets et al. (2008a; 2008b) and Roets (2009), he contends that discharge from the TMG Aquifer sustains Vankervelsvlei - a unique wetland located in the stabilised dunes east of Sedgefield - and thereafter discharges into Groenvlei. A critical review of this work indicates that the Roets conceptual model is flawed and not supported by basic geohydrological principles and available information. This paper evaluates the conceptual model in view of available information and presents an alternative model that takes account of existing information.

\section{Description of study area}

\section{Groenvlei}

Groenvlei has been described by Martin (1956), Fijen (1995) and Parsons (2008a). It has a west-east elongated shape being some $3.7 \mathrm{~km}$ long and $0.9 \mathrm{~km}$ wide. The surface area of the water body is $2.34 \mathrm{~km}^{2}$ while the surrounding vegetation in and

\footnotetext{
* To whom all correspondence should be addressed.

邑 +2721 855-2480; fax: +2721 855-2363; e-mail: $\operatorname{loger@pasgc.co.za}$

Received 15 May 2009; accepted in revised form 14 September 2009.
}

peripheral to the water body covers $1.52 \mathrm{~km}^{2}$. The lake has a perimeter of $9000 \mathrm{~m}$, while that of the total wetland is 11400 $\mathrm{m}$. The maximum depth of Groenvlei is about $5 \mathrm{~m}$, but much of the lake is less than $3.7 \mathrm{~m}$ deep (Martin, 1956). Groenvlei is located at an elevation of some $3 \mathrm{~m}$ a.m.s.l. on unconsolidated aeolian sands of Pleistocene and Recent age.

Little information is available regarding the thickness of the sands or the nature of the underlying geology. The contact between shale and quartzite of the Kaaimans Group and sandstone and quartzite of the Peninsula Formation of the Table Mountain Group is covered by sand, but is probably located directly west of the wetland (Coetzee, 1979). These rocks are at least of Ordovician age (495-443 Ma). Groenvlei started to form about 17000 years ago during the last glacial period. Martin (1959) postulated that Groenvlei had an estuarine origin, and was connected to Swartvlei some $5 \mathrm{~km}$ to the west about 8000 years ago. Wind-blown sand deposits covered the area between Groenvlei and the sea some 6000 years ago, effectively covering evidence of the lake's earlier connectivity to the sea.

The lake does not have any influent rivers, and is fed only by direct rainfall and groundwater inflow (Parsons, 2008a). This is offset by evaporation losses from the lake surface, evapotranspiration losses from vegetation in and peripheral to the water body, and subsurface discharge along the southern shores. Long-term monitoring of the water level of the lake by the Department of Water Affairs and Forestry (DWAF, now the Department of Water and Environmental Affairs) shows levels ranging between $2.25 \mathrm{~m}$ a.m.s.1. and $3.40 \mathrm{~m}$ a.m.s.l., with a median of $2.76 \mathrm{~m}$ a.m.s.l. The water level displays an interannual range of about $0.3 \mathrm{~m}$.

\section{Vankervelsvlei}

Vankervelsvlei is located about $2 \mathrm{~km}$ north-east of Groenvlei, and was described by Irving and Meadows (1997) as a floating bog. It has no open water and the peat is in the order of $10 \mathrm{~m}$ thick. Vankervelsvlei is a rare geomorphological feature located at an elevation of some $150 \mathrm{~m}$ higher than Groenvlei. 


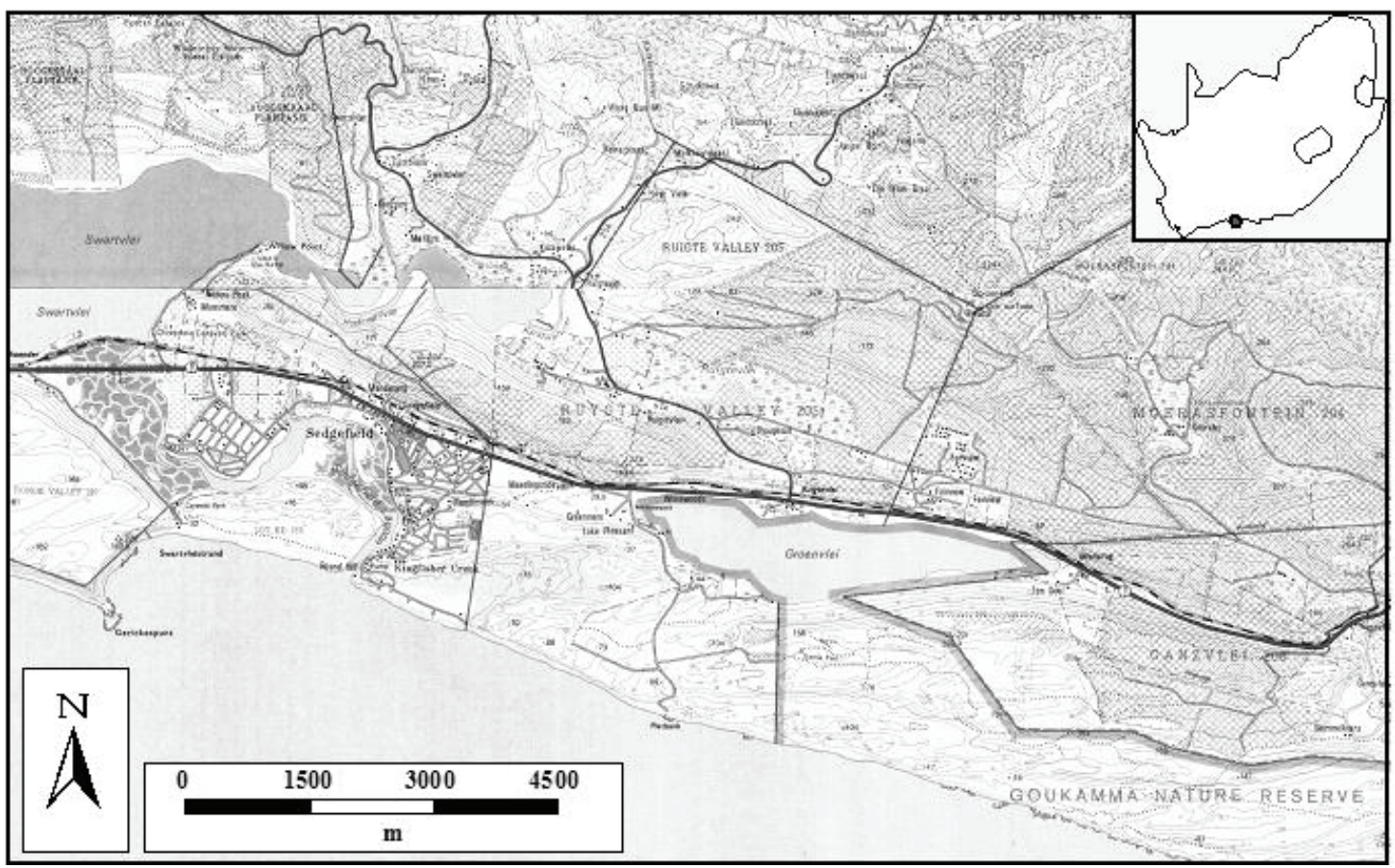

Figure 1

Locality map of the study area, showing Groenvlei and Vankervelsvlei in relation to Sedgefield

The wetland is located on a stabilised aeolian dune described by Illenberger (1996). Irving and Meadows (1997) reported that clay layers at least $3.5 \mathrm{~m}$ thick underlie the upper peat layers. The wetland is thought to overlie rocks of the Peninsula Formation of the Table Mountain Group, but the depth to the fractured aquifer system is not known. Vankervelsvlei is at an elevation of 150 $\mathrm{m}$ a.m.s.l. and covers an area of only $0.5 \mathrm{~km}^{2}$. It is an enclosed interdunal depression with no surface water inflows. Water in the wetland is completely concealed by a dense covering of matted sedge vegetation to a depth of approximately $2 \mathrm{~m}$ below the surface. The basal sediments of Vankervelsvlei have been dated at 40000 years old.

\section{Roets conceptual model}

Roets et al. (2008b) presented a hypothetical cross-section through the southern Cape coastal belt to illustrate their understanding of surface water/groundwater interaction and the role that the TMG Aquifer plays in sustaining both Vankervelsvlei and Groenvlei (Fig. 2). Their thesis is that groundwater is discharged from the confined TMG Aquifer up into Vankervelsvlei, and then flows into Groenvlei. Analysis of groundwater chemistry data is used to cement the link between the underlying TMG Aquifer and the wetlands. However, available topographical, geological, geohydrological and hydrochemical data do not support this model.

\section{Topography}

Critically, the hypothetical section misrepresented the topography of the area and incorrectly portrayed the elevation of Groenvlei in relation to both the sea and Vankervelsvlei (Fig. 3). Groenvlei is at an elevation of about $3 \mathrm{~m}$ a.m.s.l., while Vankervelsvlei is at an elevation of about $150 \mathrm{~m}$ a.m.s.l. If there is a hydraulic link between the 2 water bodies, the average hydraulic gradient would be in the order of 0.054 . This is an extraordinarily steep hydraulic gradient, the likes of which are not reported in scientific literature. Typically, hydraulic gradients range between 0.0005 and 0.01

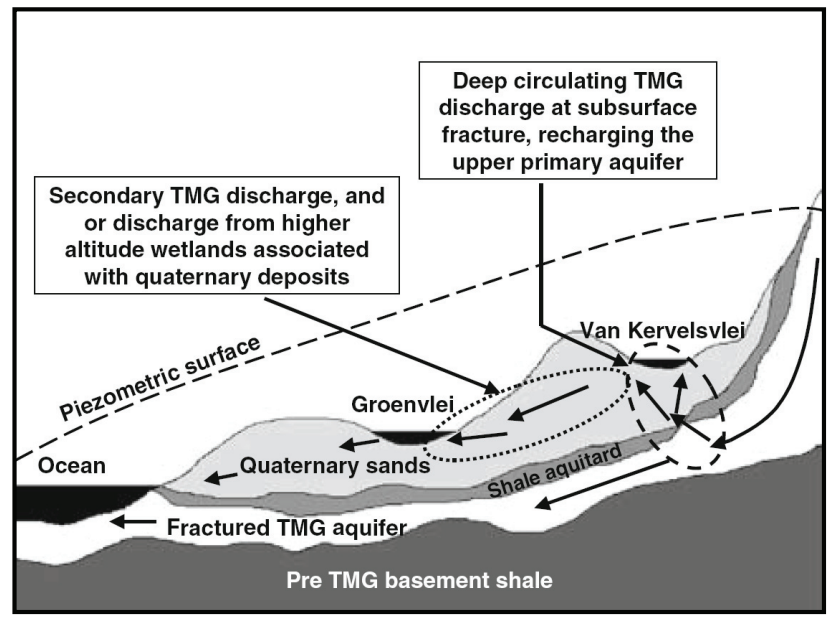

Figure 2

North/south hypothetical cross-section through the southern Cape coastal belt presented by Roets et al. (2008b) to illustrate their understanding of surface water/groundwater interaction and the role of the TMG Aquifer in sustaining Groenvlei and Vankervelsvlei.

(Hartner, 2003). The hydraulic gradients of major primary aquifers in South Africa conform to this range (Table 1). The steep hydraulic gradient postulated in the conceptual model would also result in significant groundwater discharge along the northern slope of the valley between Groenvlei and Vankervelsvlei, a phenomenon not observed in the field. Given the highly transmissive nature of the Sedgefield Aquifer and the measured hydraulic gradients ranging between 0.001 and 0.004 reported by Parsons (2005), a hydraulic gradient in the order of 0.05 is refuted.

\section{Groundwater levels}

Seven deep boreholes have been drilled into the stabilised dunes within 2 km of Groenvlei (Parsons, 1997; 2004). All are 


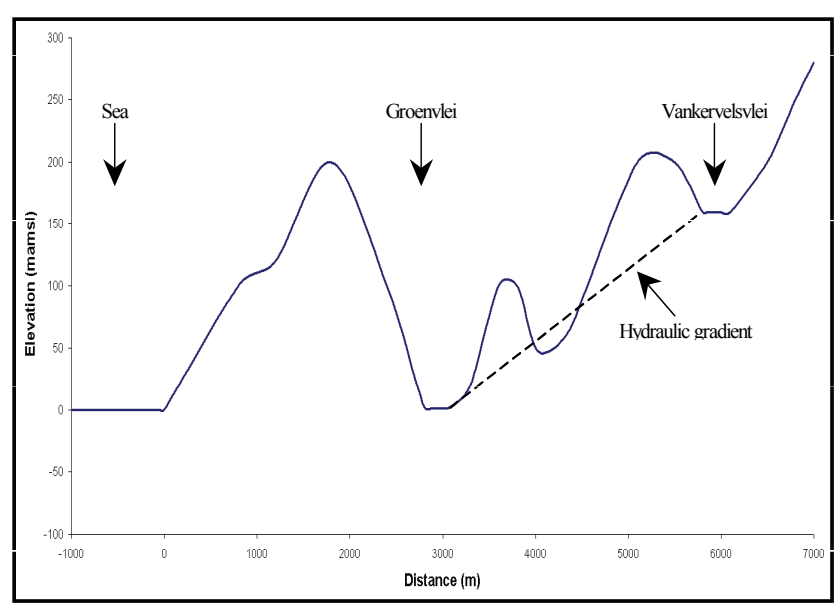

Figure 3

North/south topographical cross-section through Groenvlei and Vankervelsvlei, with a 10x vertical exaggeration. The steep hydraulic gradient of 0.054 required to link Vankervelsvlei with Groenvlei is refuted. by Irving and Meadows (1997) and means that the water body is disconnected or detached from the underlying groundwater system. This also refutes the hydraulic link between Groenvlei and Vankervelsvlei.

It is noteworthy that the groundwater levels measured in piezometers VKA and VKB do not support the piezometric surface illustrated in the Roets conceptual model (Fig. 2). Except for water levels measured by himself in shallow piezometers at 10 locations around Groenvlei and Vankervelsvlei, Roets (2008) and Roets et al. (2008a; b) fail to present or refer to any groundwater level data in support of the groundwater flow patterns illustrated in Fig. 2. The piezometric surface indicated in the conceptual model would result in widespread artesian conditions if artesian conditions existed in the manner required by the conceptual model to discharge into Vankervelsvlei. It is recognised that the piezometric head can only be measured if boreholes penetrate through the confining layer and into the confined aquifer. None of the boreholes in the vicinity of the wetlands achieve this. Further, artesian conditions are not reported in any of the regional geohydrological assessments of the area (Meyer, 1999; Parsons and Veltman, 2006). Given the absence of artesian conditions in the region and the measured borehole data presented in Table 2, it is not possible for discharges from the TMG Aquifer to lift or push up more than $150 \mathrm{~m}$ through permeable sand to sustain Vankervelsvlei.

In addition to TMG groundwater discharging from depth upwards into Vankervelsvlei, the conceptual model also requires water to be discharged from the $0.5 \mathrm{~km}^{2}$ wetland downward into the subsurface to create and maintain the hydraulic link with Groenvlei. It is simply not possible for the opposing groundwater flow directions to co-exist in such a small area.

\section{Geology}

\section{Table 2}

Deep boreholes drilled into the stabilised dunes around Groenvlei

\begin{tabular}{|l|c|c|c|c|}
\hline Borehole & $\begin{array}{c}\text { Elevation } \\
\text { (m a.m.s.I.) }\end{array}$ & $\begin{array}{c}\text { Borehole } \\
\text { Depth } \\
\text { (m) }\end{array}$ & $\begin{array}{c}\text { Groundwater } \\
\text { level } \\
\text { (m b.g.I.*) }\end{array}$ & $\begin{array}{c}\text { Groundwater } \\
\text { level } \\
\text { (m a.m.s.I.) }\end{array}$ \\
\hline BH1 & 59.3 & 72 & 55.6 & 3.7 \\
BH2 & 66.9 & 78 & 63.2 & 3.7 \\
BH3 & 53.9 & 66 & 50.4 & 3.5 \\
BH4 & 144.1 & 162 & 142.2 & 1.9 \\
BH5 & 144.5 & 162 & 143.1 & 1.4 \\
BH6 & 79.9 & 84 & 77.8 & 2.1 \\
BH7 & 41.3 & 47 & 39.4 & 1.9 \\
\hline
\end{tabular}

(from Parsons, 1997; 2004)

$*_{m}$ b.g.l. - metres below ground level

located west of the water body. In all instances, the groundwater level was measured to be within $3.7 \mathrm{~m}$ of mean sea level (Table 1). Further, groundwater level monitoring has revealed that groundwater levels display little interannual variation $(\sim 0.2 \mathrm{~m})$ (Parsons, 2006). Given that Vankervelsvlei is located in the same geological and geohydrological setting as that into which the boreholes were drilled, the water levels of $148.6 \mathrm{~m}$ a.m.s.l. and $148.8 \mathrm{~m}$ a.m.s.l. measured by Roets (2008) in piezometers VKA and VKB at Vankervelsvlei are in all likelihood perched water levels, and not representative of a regional water table or piezometric surface. The perched condition is in line with the description of Vankervelsvlei presented shape files presented in ENPAT and used by Fortuin (2004) rather than the published 1:250 000 geological map of the area (Coetzee, 1979). The position of the contact between the Kaaimans Group and the Table Mountain Group presented by Fortuin (2004) does not correlate with that presented by the more authoritative and site-specific Coetzee (1979). Use of the simplified 1:1 000000 scale geological shape file from the WR90 data set (Midgley et al., 1994) to define geology at a local scale is problematic. Some correlation exists with the ENPAT data set and that presented by Coetzee (1979), but the principle lithology of a geological unit is presented as opposed to the stratigraphic groupings. This may account for the apparent confusion regarding whether the Peninsula Formation or the Nardouw Subgroup underlies the wetlands.

Notwithstanding these differences, the geological detail presented in Fig. 2 does not conform to any of the geological information referred to above. In all likelihood, both Groenvlei and Vankervelsvlei are underlain by rocks of the Table Mountain Group (and more specifically the Peninsula Formation). Neither the thickness of the sand (depth to hard rock) nor the lithology of the underlying aquifer is known. The presence of a laterally extensive 'shale aquitard' is pure speculation and without foundation. The aquitard is required to support the thesis that Groenvlei and Vankervelsvlei are sustained by discharge from
Roets (2008) chose to rely on national geological 
the underlying TMG Aquifer as the confining layer provides the mechanism needed for groundwater from depth to flow upwards and into the wetlands. The relatively thin and distinctive Cederberg Formation, which could act as the aquitard, has not been mapped in the vicinity of the 2 wetlands (Coetzee, 1979), and interpretation of the geological map indicates that they are underlain by arenites of the Peninsula Formation. The map also indicates that the Table Mountain Group is folded. Consequently, it is improbable that the Cederberg Formation would have the near-horizontal orientation indicated in Fig. 2. The absence of the Cederberg Formation further undermines the validity of the conceptual model, and portrayal of the TMG Aquifer as a confined aquifer is a misrepresentation of prevailing geohydrological conditions.

Roets (2008, p 123) states that 'Groenvlei and Vankervelsvlei are lowland wetland systems associated with major east-west running fault systems located to the south of the Outeniqua Mountains.' At no point does he indicate where these major fault systems are, and none are indicated on the geological map of the area (Coetzee, 1979). Faulting of the Cederberg Formation is a key component of the conceptual model, as it provides the mechanism for groundwater in a confined aquifer to discharge into overlaying primary aquifer system and Vankervelsvlei. The absence of any indication of faults in the area advocates this aspect of the conceptual model to be speculative and the above statement to be without foundation.

\section{Chemical character}

Roets (2008) argues that because the electrical conductivity (EC), $\mathrm{pH}$ and concentrations of $\mathrm{Na}, \mathrm{Cl}$ and $\mathrm{Fe}$ of water sampled from shallow wellpoints at 2 sites at Vankervelsvlei and 3 sites around Groenvlei - all collected on 30 July 2006 - fall within ranges presented by Brown et al. (2003) as being typical of groundwater from the TMG Aquifer, the sampled water must originate from the deeper secondary aquifer system. In their report, Brown et al. (2003) presented a table from Smith et al. (2002) that displayed the mean, minimum and maximum for 13 chemical parameters from 75 boreholes drilled into the Nardouw Subgroup and 28 boreholes drilled into the Peninsula Formation in the Klein Karoo.

By simply comparing 5 chemical parameters measured at the 5 sites at Vankervelsvlei and Groenvlei to ranges considered by Brown et al. (2003) as being typical of groundwater from TMG aquifers, Roets $(2008$, p. 138) concludes that 'the hydrochemical data of the groundwater from this study suggests that Vankervelsvlei and Groenvlei are dependent on groundwater from the TMG Aquifer.' DWAF's hydrochemical database contains $14377 \mathrm{EC}$ records from boreholes located in a variety of aquifer types across the Western Cape Province. Of these, $56.3 \%$ have an EC in the range of 9 to $155 \mathrm{mS} / \mathrm{m}$. Consequently, this EC range is not unique to TMG Aquifers and cannot be used for hydrochemical 'finger printing' purposes.

A review of the range of EC from 4 major coastal primary aquifer systems across South Africa shows that the EC range displayed by the small data set collected by Roets (2008) is within the range of EC displayed by the Sedgefield Aquifer, the Atlantis Aquifer, the Cape Flats Aquifer and the Zululand Coastal Aquifer around St Lucia (Fig. 4). Only the Sedgefield Aquifer is partially underlain by rocks of the Table Mountain Group, with the other aquifers having no connection to the Group at all. It is far more likely that groundwater quality characteristics displayed by Roets's data are typical of coastal primary aquifers rather than TMG Aquifers. As the chemical

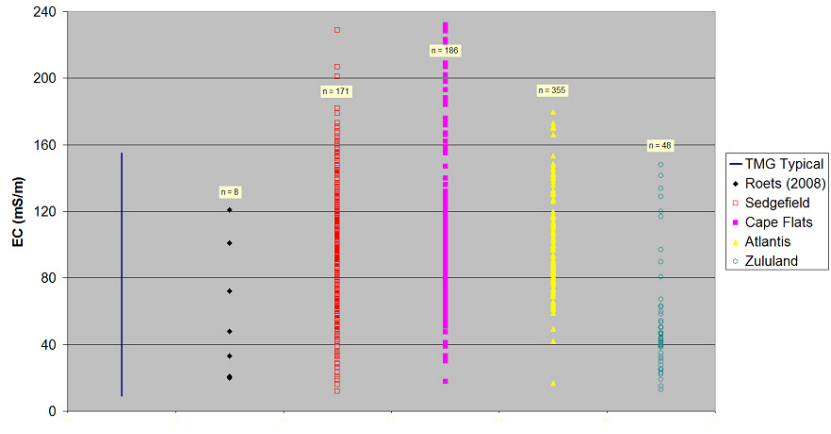

Figure 4

The range of EC displayed by groundwater in four major coastal primary aquifers, compared to data presented by Roets (2008) and the EC range considered by Brown et al. (2003) to be typical of groundwater from the Table Mountain Group Aquifer

character typical of coastal primary aquifers across South Africa overlaps with that of TMG groundwater, the relation is coincidental rather than causative. The interpretation that the chemical character of groundwater adjacent to the 2 wetlands is indicative of a TMG Aquifer link is wrong.

Roets (2008, p. 139) attempts to cement his argument that Vankervelsvlei is fed by groundwater from the TMG Aquifer by attributing the iron $(\mathrm{Fe})$ concentration of 382.23 $\mathrm{mg} / \ell$ recorded in VKB $(11 \mathrm{~m})$ to 'the presence of the Nardouw Formation'. Notwithstanding the fact that the geological map of the area indicates that Vankervelsvlei is underlain by the Peninsula Formation and not by the Nardouw Subgroup and significantly lower Fe concentrations were recorded at shallower depths at the same site $(0.5 \mathrm{~m}=9.5 \mathrm{mg} / \ell ; 1 \mathrm{~m}=7.0$ $\mathrm{mg} / \ell$ ), Fe concentrations such as these are unprecedented. High Fe concentrations of some $30 \mathrm{mg} / \ell$ monitored by Parsons (2008b) at Arabella Country Estate are thought to represent the upper levels of Fe in groundwater, while Smith et al. (2002) set the maximum $\mathrm{Fe}$ concentration of the 2 geological units at $0.2 \mathrm{mg} / \ell$ and $15.4 \mathrm{mg} / \ell$. A concentration an order of magnitude higher than these maxima is hence improbable. If the value of $382 \mathrm{mg} / \ell$ is not a laboratory-related error, then Fe contained in the vegetative mat in Vankervelsvlei deserves closer scrutiny.

Roets (2008) compares his groundwater quality data to the chemical character of groundwater from the Nardouw Subgroup. Interpretation of the 1:250 000 scale geological map of the area (Coetzee, 1979) suggests that Groenvlei and Vankervelsvlei are underlain by the Peninsula Formation and not the Nardouw Subgroup. The EC range presented by Brown et al. (2003)) for the Peninsula Formation is much narrower ( $3 \mathrm{mS} / \mathrm{m}$ to $26 \mathrm{mS} / \mathrm{m}$ ) than for the Nardouw Subgroup $(9 \mathrm{mS} / \mathrm{m}$ to $155 \mathrm{mS} / \mathrm{m}$ ), and only $25 \%$ of Roets's data fall within the Peninsula Formation range.

\section{Discussion}

Roets (2008) and Roets et al. (2008b) used multivariate cluster analysis of mean EC values to group piezometer positions displaying the same or similar EC characteristics. They over-interpreted the results by stating that the groundwater at the different locations has a 'shared groundwater source', as the statistical analyses merely point to a similar character. They make similar and repeated claims that all data presented by them points to the 2 wetlands being dependent on groundwater from the TMG Aquifer, and the 2 wetlands being hydraulically linked. Based on available information and an evaluation of the information 


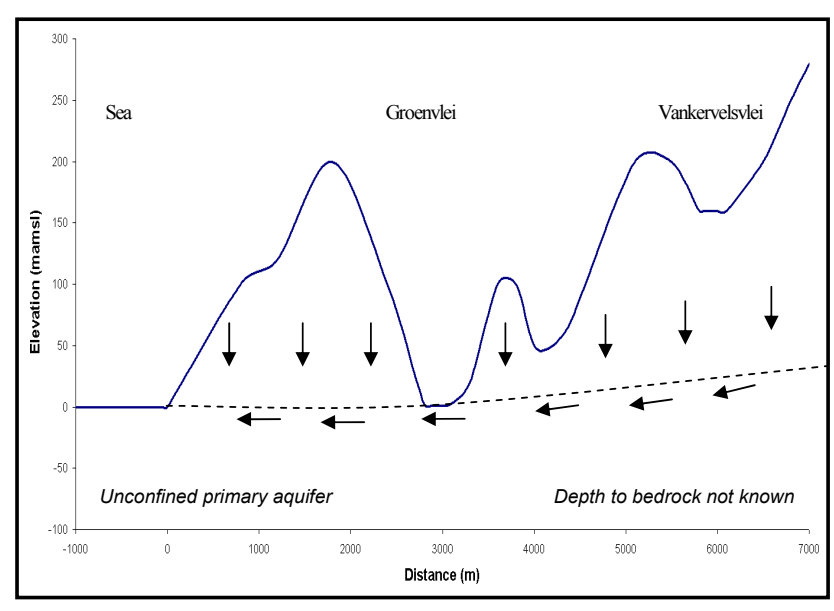

Figure 5

An alternative conceptual geohydrological model of the study area based on available topographical and hydrological data

presented by them, they have failed to provide any scientifically credible evidence that either Vankervelsvlei or Groenvlei are fed by discharges from the TMG Aquifer or that the 2 wetlands are hydraulically linked. Consequently, any conclusions and recommendations based on their hypotheses are without standing.

A major weakness of the reviewed research of Vankervelsvlei is that it did not consider the fact that the floating bog is solely sustained by direct rainfall. The absence of surface runoff, the expected depth of the regional water table and the low ECs measured by Roets (2008) support this interpretation. It is noteworthy that Parsons (2008a) estimated that direct rainfall accounted for almost $40 \%$ of the inflow into Groenvlei, while direct rainfall accounts for $38 \%$ of the freshwater input into Lake St Lucia (Van Niekerk, 2004). Both Irving and Meadows (1997) and Roets (2008) reported that Vankervelsvlei has no open water. The wetland can be sustained by a relatively small volume of water as the impermeable character of the base of the vlei prevents or restricts the downward percolation of water, and the absence of a dry season results in the vlei being continually recharged by rainfall. Water retention in the vlei is further enhanced by the dense sedge vegetation concealing the water surface (and hence reducing direct evaporation losses) while the organic nature of the soils promotes soil moisture retention. The rainwater-fed theory is both simple and plausible while the convoluted TMG Aquifer-fed theory is not supported by available geohydrological data or geohydrological principles.

An alternative conceptual model based on available geological and geohydrological information is presented in Fig. 5. It is acknowledged that the depth to bedrock is not known, but based on information presented by Coetzee (1979) it is likely to comprise rocks of the Peninsula Formation. The unconfined primary aquifer system is fed by recharge from rainfall that percolates through the vadose zone until it reaches the regional water table of the primary aquifer. The regional hydraulic gradient is typical of that of transmissive primary aquifers and is in the range of 0.001 to 0.004 reported by Parsons (2008a). Depth to the regional water table at Vankervelsvlei is predicted to be in the order of $145 \mathrm{~m}$ below ground level. Vankervelsvlei is fed by direct rainfall only, with a low permeability clay base preventing or retarding the downward percolation of water in the wetland to the aquifer. By contrast, Groenvlei is fed by both direct rainfall and groundwater. There is no hydraulic link between the 2 wetlands, with Vankervelsvlei being described as a disconnected system. Groenvlei is a flow-through system, as described by Born et al. (1979).

It is not claimed by Roets (2008) that Groenvlei is fed directly from the TMG Aquifer. Rather it is hypothesised that TMG groundwater discharges into Vankervelsvlei and then discharges from the wetland into Groenvlei (Fig. 2 -'secondary discharge'). However, given Groenvlei's low elevation and proximity to the coast, it is theoretically possible that deep circulation in the TMG Aquifer could discharge into the Sedgefield Aquifer, and thereby sustain Groenvlei. The study of such a theory will require the drilling of a large number of deep boreholes into the TMG Aquifer, supported by hydrochemical and isotopic examination. Until such time that there is any evidence of Groenvlei being sustained by discharges from the TMG Aquifer, such theories should be treated with circumspection.

\section{Conclusions}

It is concluded that Roets $(2008 ; 2009)$ and Roets et al. (2008a; b) failed to provide any credible scientific evidence that either Vankervelsvlei or Groenvlei are fed by discharges from the TMG Aquifer or that the 2 wetlands are hydraulically linked. The conceptual model presented by them is not supported by available geohydrological data or geohydrological principles. Their thesis is based on speculation and lacks scientific rigour, having failed to consider water sources other than that from the TMG Aquifer. The interpretation that the chemical character of groundwater adjacent to the 2 wetlands is indicative of a TMG Aquifer link is wrong, as the character typical of coastal primary aquifers across South Africa overlaps with that of TMG groundwater. There is no hydraulic link between Vankervelsvlei and Groenvlei, and the former wetland is fed only by direct rainfall. Groenvlei is fed by direct rainfall and groundwater, and the possibility that it is being fed by the underlying TMG Aquifer requires further research before it can be given credence.

\section{Acknowledgements}

The provision of groundwater quality data by Mrs Rooseda Peters of the Department of Water and Environmental Affairs is gratefully acknowledged. Review of an earlier version of this paper and guidance provided by Prof. Mike Meadows and Prof. Gerrit van Tonder were extremely helpful. The constructive comments of the 2 anonymous reviewers are also acknowledged.

\section{References}

BORN SM, SMITH SA and STEPHENSON DA (1979) Hydrogeology of glacial-terrain lakes, with management and planning applications. J. Hydrol. 43 7-43.

BROWN C, COLVIN C, HARTNADY C, HAY R, LE MAITRE D and RIEMANN K (2003) Ecological and Environmental Impacts of Large-Scale Groundwater Development in the Table Mountain Group (TMG) Aquifer System. Draft discussion document for WRC Project No. K5/1327 (unpublished). Water Research Commission, Pretoria, South Africa.

COETZEE F (1979) 3322 Oudtshoorn - 1:250 000 Geological Map Series. Geological Survey, Pretoria, South Africa.

DU TOIT IM and WEAVER JMC (1995) Saldanha Steel Project Groundwater Investigation. Report No. 27/95, Watertek, CSIR, Stellenbosch, South Africa. 
DYKE G (1992) Western Cape Systems Analysis - A Review of the Groundwater Resources of the Western Cape. Report No. P G000/00/2591, Department of Water Affairs and Forestry, Pretoria, South Africa.

FIJEN APM (1995) Groenvlei Lake Catchment Water Management Strategy Main Report. Department of Water Affairs and Forestry, Pretoria, South Africa.

FLEISHER JNE (1990) Atlantis Groundwater Management Programme - the Geohydrology of the Witzand Wellfield. Report No. 2/90, Watertek, CSIR, Stellenbosch, South Africa.

FORTUIN M (2004) A Geographical Information System Approach to the Identification of Table Mountain Group Aquifer "Type Area" of Ecological Importance. Unpublished M.Sc. Thesis, University of the Western Cape, Cape Town, South Africa.

HARTNER T (2003) Basic Concepts of Groundwater Hydrology. ANR Publication 8083, University of California, California, USA.

ILLENBERGER WK (1996) The geomorphic evolution of the Wilderness dune cordons, South Africa. Quaternary Int. 33 11-20.

IRVING SJE and MEADOWS ME (1997) Radiocarbon chronology and organic matter accumulation at Vankervelsvlei, near Knysna, South Africa. SA Geogr. J. (Special Edition) 101-105.

MARTIN ARH (1956) The ecology and history of Groenvlei. S. Afr. J. Sci. (March 1956) 187-198.

MARTIN ARH (1959) The stratigraphy and history of Groenvlei, a South African coastal fen. Aust. J. Bot. 142-167.

MEYER PS (1999) An Explanation of the 1:500 000 General Hydrogeological Map - Oudtshoorn 3320. Department of Water Affairs and Forestry, Pretoria, South Africa.

MEYER R, TALMA AS, DUVENHAGE AWA, EGLINGTON BM, TALJAARD J, BOTHA F, VERWEY J and VAN DER VOORT I (2001) Geohydrological Investigation and Evaluation of the Zululand Coastal Aquifer. WRC Report No. 221/1/01, Water Research Commission, Pretoria, South Africa.

MIDGLEY DC, PITMAN WV and MIDDLETON BJ (1994) Surface Water Resources of South Africa 1990. WRC Report No. 298/1/94. Water Research Commission, Pretoria, South Africa.

PARSONS RP (1997) Establishment of a Groundwater Monitoring Network at the New Sewage Treatment Plant, Sedgefield; Report 001/SEDM-1, Parsons \& Associates Specialist Groundwater Consultants $^{\mathrm{cc}}$, Somerset West, South Africa.

PARSONS RP (2004) Exploratory Drilling and Testing of Boreholes to Augment Water Supplies to Sedgefield. Report No. 142/NINS-D1, Parsons \& Associates Specialist Groundwater Consultants ${ }^{\mathrm{cc}}$, Somerset West, South Africa.

PARSONS RP (2005) Groundwater Use at the Lake Pleasant Chalets \& Lodges, East of Sedgefield. Report No. 166/LPC-D1, Parsons \& Associates Specialist Groundwater Consultants ${ }^{\mathrm{cc}}$, Somerset West, South Africa.

PARSONS RP (2006) Review of Groundwater Monitoring at Sedgefield April 2005 - January 2006. Report No. 187/NINS-1,
Parsons \& Associates Specialist Groundwater Consultants ${ }^{\mathrm{cc}}$, Somerset West, South Africa.

PARSONS RP (2008a) Quantify Groundwater's Role in Sustaining Groenvlei, a Shallow Lake in the Southern Cape Region of South Africa. International Association of Hydrological Sciences Publ. 320, IAHS Press, Wallingford, United Kingdom.

PARSONS RP (2008b) Arabella Country Estate: Groundwater Monitoring - October 2008. Report No. 228/ARAB- D1, Parsons \& Associates Specialist Groundwater Consultants ${ }^{\mathrm{cc}}$, Somerset West, South Africa.

PARSONS RP and VELTMAN S (2006) Outeniqua Coast Water Situation Study - Groundwater Resources. Report No. 167/UWP prepared in association with the Department of Water Affairs and Forestry for UWP Consulting (Pty.) Ltd. and BKS (Pty.) Ltd., Parsons \& Associates Specialist Groundwater Consultants ${ }^{\mathrm{cc}}$, Somerset West, South Africa.

ROETS W (2008) Groundwater Dependence of Aquatic Ecosystems Associated with the Table Mountain Group Aquifer. Unpublished Ph.D. Thesis, University of the Western Cape, Cape Town, South Africa.

ROETS W, XU Y, RAITT L and BRENDONCK L (2008a) Groundwater discharges to aquatic ecosystems associated with the Table Mountain Group (TMG) Aquifer: A conceptual model. Water SA 33 (1) $77-87$.

ROETS W, XU Y, RAITT L, EL-KAHLOUN M, MEIRE P, CALITZ F, BATELAAN O, ANIBAS C, PARIDAENS K, VANDENBROUCKE T, VERHOEST NEC and BRENDONCK L (2008b) Determining discharges from the Table Mountain Group (TMG) aquifer to wetlands in the Southern Cape, South Africa. Hydrobiol. 607 175-186.

ROETS W (2009) Groundwater contributions to surface resources in the Table Mountain Group Aquifer. Proc. Conf. Implementing Environmental Water Allocations. 23-26 February 2009, Port Elizabeth, South Africa.

SMITH ME, CLARKE S and CAVE LC (2002) Chemical evolution of Table Mountain Group groundwater and the source of iron. Proc. Conf. Ground Water Division. Sept. 2002, Somerset West, South Africa. 47-52.

TIMMERMAN LRA (1985) Preliminary report on the geohydrology of the Grootwater Primary Aquifer Unit between Yzerfontein and the Modder River. Technical Report No. Gh3372, Directorate of Geohydrology, Department of Water Affairs and Forestry, Cape Town, South Africa.

VAN NIEKERK L (2004) Preliminary Determination of the Ecological Reserve on a Rapid Level for the Lake St Lucia Estuary. Report No. ENV-S-C 2004-, Environmentek, CSIR, Stellenbosch, South Africa.

WRIGHT A and CONRAD JE (1995) The Cape Flats AquiferCurrent Status. Report No. 11/95, Watertek, CSIR, Stellenbosch, South Africa. 